\title{
Intellectuals and State Construction: On Advocates of Good Governmentalism of Hu Shih Scholars during May $4^{\text {th }}$ Period
}

\author{
Lei Wang \\ Jiangsu Provincial Research Center for the Theory of Socialism with Chinese Characteristics \\ Nanjing Normal University \\ 210023, Nanjing, China \\ 14200@njnu.edu.cn
}

\begin{abstract}
As midwives of a new era, intellectuals are playing a pivotal role in the construction of the modern state at any time. Group of scholars as the core of $\mathrm{Hu}$ Shih also gave them own observation and efforts, put forward and practice the modern state founding ideas of "Good Governmentalism" in May Fourth Period. As an important part of modern Chinese advanced molecular, although advocates of the group of $\mathrm{Hu}$ Shih scholars were still some distance away from the reality of China, it appeared itse If was a kind of exploration of the way out for China, as well as enriched and developed the concept and practice of state cons truction in modern China.
\end{abstract}

Keywords-May 4th Period; Intellectuals; State Construction; Good Governmentalism

\section{INTRODUCTION}

Night gives them black eyes, but they use it to find light. As the eyes of the times, since the late Qing Dynasty, Chinese intellectuals have always played an important role as "the birthplace of the new era", and once "reached a new peak" in the May 4th period. ${ }^{[1]}$ World War I, the October Revolution, Paris Peace Conference have deeply influenced the concept cognition and practice choice of them. The intellectuals' cognition, choice and practice of different '-Ism's during May 4th Period not only shaped intellectuals themselves, but also affected the structure of modern China. What's more, their different cognitions about China's reality, claims of reforming the state and practice itself constituted the organic composition of the growth of the concept of modern Chinese nation-state cognition. Liberalism, an intellectual group and the core of it was Hu Shih, which meant that Hu Shih school crowd was the typical representatives of it.

\section{THE BACKGROUND AND EXPERIENCE OF "GOOD}

\section{GOVERNMENTALISM" ADVOCATED BY HU SHIH' S CROWD}

$\mathrm{Hu}$ Shih, who had decided to recreate culture for China early in his stay in the USA, immediately, joined the new cultural movement of spreading new thoughts after returning to China, determined to 'build a foundation for the innovation of Chinese politics in the field of thought and literature ".

Sponsored by A Project Funded by the Priority Academic Program Development of Jiangsu Higher Education Institutions (PAPD), Jiangsu University Philosophy and Social Sciences Planning Fund Project (2016SJB710003)
However, though determined Twenty years without politics, $\mathrm{Hu}$ Shih had al ways been hampered by actual politics, making him eventually "can’t help but" talk about politics. ${ }^{[2]}$

Certainly, Hu Shih's "angry to talk about politics" reasons, whether himself or later researchers have given many explanations. ${ }^{[3]}$ I believe, The reason why Hu Shih changed his original intention of "talking without politics" has his own personal factors, but to a large extent, caused by the actual environment. Warlord repression, political corruption made all intellectuals who were deeply edified by practical thoughts can't but have the responsibility and impulse to interfere in politics. Hu's friend Ding Wenjiang thinks, "good politics is the essential condition for the improvement of any peaceful society", the claim that "talking without politics" in twenty years is a delusion, and intellectuals must give full play to the "responsibility of the minority". ${ }^{[4]}$

Since despicable and corrupt politics even didn't let go of students, leave alone the teachers and other intellectuals, and the arrest of Chen Duxiu was clear evidence. If the highhanded policy of the Northern Warlords against other intellectuals had not yet touched $\mathrm{Hu}$ Shih, the arrest of this fellow countryman, colleague and comrade-in-arms in the same trench had brought great stimulation to Him. One of the results was took over Weekly Review, "a newspaper talking about politics", co-founded with Chen Duxiu, adding to the "talk politics" team. ${ }^{[5]}$ While Declaration of Arguing for freedom, another paper he published with Li Dazhao and others, Once again expressed the stimulation of real politics to $\mathrm{Hu}$ Shi. ${ }^{[6]}$

From the publishment of Declaration of Freedom to the establishment of the Endeavor and the publishment of Declaration of Arguing for freedom, Hu Shi's 'Good Governmentalism' claim had experienced a gradual deepening process. As to the fact that some young people considered anarchism a king of fashion, Hu Shih considered it "a big mistake". From his perspective, "It's definitely wrong to talk about anarchism at will right now", we should "talk about having government doctrine and Good Governmentalism". ${ }^{[5]}$ In the summer of 1921, Hu Shih spoke about his "way to freedom" via the mouth of " a philosophy" : " It only ten thousand good people to save China. ", even though we don't have so much, we can go with a " dozen " or two. 
On $5^{\text {th }}$ August of the same year, 'the first open talk about politics" of Hu Shih was the publishment of the speech "Good Governmentalism". In his view, "Good Governmentalism is a kind of Having Governmentalism", 'the basic concept of Good Governmentalism is a kind of political instrumentalism",-"The government is the tool that society uses to seek the greatest majority of the welfare, so all who can do this duty is a good government, can't do this duty is a bad government. It is a bad government that hampers or destroys social welfare. " "We have to keep a simple and understandable goal--Good Government", 'We need a group of good guys to gather together to fight for this goal positively. If good people don't show up, bad guys will carry the world!" ${ }^{[5]}$ After returning to Beijing, $\mathrm{Hu}$ Shih took the opportunity of celebrating the Double Tenth Festival to persuade people to "remember it in a different way". Everyone united to drive out the wolves, overthrow the bad government, start a new revolution and build a good government: that is the commemoration of the Double Tenth Festival! ${ }^{[5]}$

Just as $\mathrm{Hu}$ Shih changed his original intention of "not talking about politics" and talked about "Good Governmentalism", under the background that Hu Shi changed his initial mind, and talk about "Good Governmentalism", the Endeavor started publication in May 1922. Nearly 20 famous people joined in, such as Ding Wenjiang, Ren Hongjun, Chen Hengzhe, Gao Yihan and Cai Yuanpei, which marked the first gathering of Chinese liberalism scholars. These highly educated and overseas scholars (even some of them have not studied abroad have educational experience in domestic institutions of higher learning) with more prominent social identities gather to discuss political issues and publish their views on the current situation through gatherings, publications and declarations, which opened up the first step for the liberalism intellectuals interfere in politics.

\section{CONTENT AND RESPONSE OF THE POLITICAL DESIGN OF "GOOD GOVERNMENTALISM"}

On $14^{\text {th }}$ May of 1922, Our Political Claims drafted by $\mathrm{Hu}$ Shi and formed in the discussion with Cai Yuanpei and $\mathrm{Li}$ Dazhao, was officially published. As 'the first systematic genenration of liberalism", Claims "formed the platform of what was later called Good Men's Government". ${ }^{[7]}$

Firstly, "the goal of political reform". Claim thinks that "No matter what their ideal political organization is, the domestic elites should now be downgraded to recognize the goal of a good government as the minimum requirement for reforming China's politics," and "work together to fight the evil forces in the country with this common goal." Secondly, the meaning of "good government". Claim puts forward that "on the negative side, there must be a proper organ which can supervise and prevent all lawless official from engaging in malpractice. On the positive side, there are two points: (1) full use of political institutions for the full benefit of the society; (2) Fully accommodated Personal freedom, love the development of personality." Thirdly, "three basic principles of political reform", That is, "constitutional government", "open government" and "planned politics". Fourthly, "the only way to political reform". Claim deeply believes that "the first step in today's political reform is that good people need a fighting spirit. All outstanding elements in society should be selfdefense. For the sake of social state, everyone should come out and fight against evil forces." Fifthly, it talks about "opinions on current political issues". Hu Shih and others have put forward their own opinions on several specific issues, such as "peace talks between the north and the south", "reduction of troops", "electoral system" and 'finance".

The publishment of Our Political Claims stirred a heated discussion in society. Just ten days after the publication, $\mathrm{Hu}$ received 14 discussions on the article. In addition, Ding Wenjiang and others, as well as Beijing Morning Post, Shanghai Daily of the Republic of China and other newspapers also published many articles on "Good Governmentalism".

Just as people enthusiastically participated in the discussion of "good governmentism", the three "good guys" who signed the "Claims", Wang Chonghui, Luo Wengan and Tang Erhe were appointed as the Prime Minister, the Chief Financial Officer and the Chief Education Officer respectively. Full of joy. From Hu Shih's view, the "good man government", which he had been looking forward to, finally had a chance to realize. Therefore, there is great expectation to $\mathrm{Hu}$ shih for Wang Chonghui's cabinet, "I hope he will come with a plan" ${ }^{[9]}$ to restore social order, and personally worked out a "plan to solve the current situation", repeatedly stressed that "a mediocre plan is better than no plan!" ${ }^{[10]}$

However, the crux of the problem is not whether Wang Chonghui, who entered the cabinet, is a "good man", but these intellectuals without real power are destined to become "married clothes" of Taoist warriors. When the warlords with real power regard "good man" uselessness and obstacles, they can easily find an excuse to knock them. After more than two months' insisting on, the "good man government", that Hu Shih and other liberal intellectuals eagerly awaited, had to declare bankruptcy. Intellectuals who are powerless can only fight against the tyrannical tyranny of the warriors in a weak and sad way of non-cooperation. [11]. Since then, the "Good Governmentalism" has been in the dark. Hu Shih himself finally realized that the "good man" government does not mean "good" government. [12]

\section{EVAlUAtion OF THE STATE CONSTRUCTION EFFORTS OF HU SHIH SCHOLARS}

Scholars at home and abroad have always attached great importance to the nation-building efforts, especially to its "Good Governmentalism" proposition. Whether at that time or later, the evaluation was numerous and inconsistent. Those who agree, "'the good government' has the least meaning. It is plain and clear that it is possible to do it completely. I'm absolutely in favor of it, and I'm willing to do my utmost to publicize it ${ }^{\text {t13]; }}$; critics have it that "your proposition of too little effort and too indecision is that the death penalty has been imposed before it is realized" ${ }^{\text {[14] }}$; and regret has it that "more than a year ago, $\mathrm{Hu}$ Shih and others passionately called on people to 'work hard' and the results of their efforts. But nothing was gained. At this time, the resounding of heart is not passion but melancholy." ${ }^{\text {"15] }}$ Circumstances change with the passage of time, looking at $\mathrm{Hu}$ 
Shih's "efforts" from today's perspective, there are also many gains.

\section{A. As a part of the advanced elements in modern China,} the liberal intellectuals of Hu Shih School have historic and progressive significance to the efforts of China's modern state construction.

Firstly, the transformation from traditional to modern is a typical feature of modern Chinese society. No matter how people reflect on modernity from the perspective of postmodernity, it is undeniable that modernity communication and its construction in modern China are fundamentally progressive and conform to the trend of Chinese historical development. The construction of nation-state has also become the theme of the development of modern Chinese history. At the same time, all classes and strata in modern China have given their own designs and efforts to construct what kind of nation-state and how to construct its historical theme. Liberal intellectuals are no exception. As the nation and the state are increasingly reduced to the tools of the warlord powers for power and gain, the national authority is lost, the social order is chaotic, and the whole country is surrounded by political, social and cultural crises. Naturally, liberal intellectuals, as spokesmen for the interests of the national bourgeoisie and the petty bourgeoisie, will not stand idly by. This idea of "good man politics" and "good man government" fully reflects the desire of the national bourgeoisie and the petty bourgeoisie for restoring social order and establishing political authority, and to a certain extent represents the trend of China's historical development and the demands of the Chinese people for stability and unity, and has historical progressive significance.

Secondly, unlike the hypocritical pursuit of modernity by Yuan Shikai and the Beiyang Warlords, the liberal intellectuals are sincere in their desire to rebuild social order and restore national unity. In their view, that sense of order in chaos, "any point of stability, no matter how fleeting or immediately disillusioned, should be cherished ${ }^{[16] p 216}$. In many people's view, Hu Shih, Ding Wenjiang and other people 'talk about politics" is irresponsible, I think, this is really grieving them. Because Ding Wenjiang and others "encouraged his friends to come out to discuss politics, criticize politics and interfere in politics", the reason lies in their "dissatisfaction with the politics of the time", fearing that under the control of the new warlords, "Chinese politics will inevitably become more irregular, corrupt and darker". It is precisely because they saw the whole country in the warlord scuffle increasingly destroyed, so they issued such a call: "Since 1917 or 1918, good people have been watching China split, watching the war against the southwest, watching the establishment and rampancy of Anfu, watching the loss of Mongolia, the sale of Shandong, warlords run across, and the country go bankrupt to this field! That's enough! The good guys can get up now! "

Thirdly, because most of these liberal intellectuals have overseas study background, have high level of expertise, and have lived in western countries for many years, have a wealth of experience, they do not have much political trickery like warlords, politicians, leaders of the academia, but in the theoretical understanding of modernity, are far higher than them. Although the theory and system design of China's modern state construction often come from good wishes and practice itself is often far away from the state conditions, from the perspective of the growth of the concept of modern China's nation-state, their understanding of a series of problems, such as sovereignty independence, national unity, democratic politics and so on, no matter in breadth or depth, they had reached a higher level. Especially rare is that these specialist intellectuals with Western background, when facing the problem of western theory and Chinese reality, initially realized the problem of combining western theory with Chinese reality. They opposed empty talk and emphasized the idea of multiresearch, which was also recognized and absorbed by Marxists. Efforts have been made to combine western theories with Chinese realities.

\section{B. Admitted that under the warlord dictatorship and imperialist politics, the "Good Governmentalism" efforts have the inevitability of failure and are not enough to change the fate of country.}

On the liberalism of modern China, Mr. Yin Haiguang once reached the famous conclusion of "congenital deficiency, acquired imbalance".[1]p267-268 Under this framework, Hu Weixi and others further pointed out several paradoxes of liberalism in modern China. That is, 'the conflict between instrumental rationality and value rationality", "the disconnection between conceptual figures and action figures", and 'the confusion between radicalness and conservatism". ${ }^{[15] p 45-59}$

To some extent, these reflections had examined the reasons for the failure of liberal state construction efforts. The failure of Hu Shi School's "Good Governmentalism" during May Fourth Period is inevitable, which is manifested in the "deviation between the concept of freedom and the practice of reality". There is no doubt that liberalism as a way to save the nation has its value and rationality in modern China. The question is how liberal freedom and order could be achieved under the conditions of warlord infighting in the early 1920s, and the idea of letting the warlords abandon their own struggle for power and profit was clearly not workable. As we all know, the time when the idea of "Good Governmentalism" was put forward was the time when Cao Kung, Wu Peifu and Zhang Zuolin launched a big fight. These intellectuals will naturally gain the support of the warlords when their claims and demands are in accord with the interests of the warlords or at least do no harm to the interests of them. This is why Wang Chonghui can form a cabinet. However, in the view of the warlords, these concepts and rules have constrained their expansion interests; of course, they will not allow it to continue to exist.

Essentially, under the circumstances of imperialism and warlord politics, any political efforts of intellectuals can't escape the fate of being reduced to tools. As it was pointed out that, 'In a situation where you can't take the political initiative yourself, trying to "good man's efforts" to reorganize politics to the contrary of the interests of the dominant forces, this is not the dream of a dull boy, is the liar's promise." ${ }^{[17]}$ For example, in the design of "good government" by $\mathrm{Hu}$ Shih and others, "good people" is the key to "the minimum requirement of reforming Chinese politics". So who can be called "good guys"? Hu Shi believed that "one is the reliability of personality; the other is that talent can be done". ${ }^{[18]}$ This conception of "elitist 
politics" and "moral idealism" thought that as long as "good people" came to govern, there would be good democratic politics, which was obviously the wishful thinking of liberal intellectuals. Because the key to Chinese politics in the 20th century was not who ruled, but who empowered you to rule. Under the warlord politics, the natural warlord has the final say. Only those who represent the interests of the majority can be ruled by democracy. The problem is not whether the people on stage are good or bad, but whether there are sound systems, laws and regulations to prevent the good from becoming bad and the bad from making bad.

\section{The objective view of the relationship between $\mathrm{Hu}$ Shi's and Marxist in the May ${ }^{\text {th }}$ period and its status in the history of modern Chinese thought.}

The above theme has always been a hot topic in the study of modern Chinese intellectual history. The traditional mainstream view criticized the improvement of Hu Shih's ideas from the angle of opposition and difference, rarely talking about its progressive meaning. I think that although there is a great difference between Hu Shi's ideas and the Marxists at that time, there are still many common points, which exactly accommodated and embodied the trend and tendency of modern Chinese thought development.

First of all, as far as the relationship between the two ideas is concerned, they have a common understanding of value pursuit and ideological goals. For example, in criticizing feudal autocracy and ignorance, the two have the same goal. The new cultural movement launched by Chen Duxiu and $\mathrm{Hu}$ Shih objectively created conditions for the spread of new ideas. The ideas of freedom, democracy, science and rationality advocated by liberalism are also endorsed by Marxism. To some extent, the enlightenment efforts have laid the scientific principles and value beliefs for the spread and Sinicization of Marxism. Moreover, the attitude and viewpoint of liberalism towards externalism and China's national conditions are also recognized, accepted and carried forward by Marxism.

Secondly, according to the practice of the two country claims in China during the May ${ }^{4 \text { th }}$ Movement, the two claims have the same direction, and in the practical work, they can also fight side by side and take care of each other. Hu Shih School's liberal intellectuals strived for the independence, order and unity of the country to pursue modernity and establish a modern state as well as Marxists. Although the two beliefs are different, and there have been several arguments over specific issues, but in most of the struggle in the early 1920s, liberals such as Hu Shih, Marxists such as Chen Duxiu, have achieved mutual support. When Hu Shih put forward the 'good government' proposition, his first thought was to discuss with Li Dazhao and to get Li Dazhao's significant support and practical help..$^{[12] p 382-383}$ In response to Chen Duxiu's proposal of "a strong political party with a strong national democratic organization", Hu also 'fully agreed" with him. ${ }^{[19]}$

Last, the position of "Good Governmentalism" advocated by $\mathrm{Hu}$ Shih's intellectuals in thought history. As mentioned above, the transition from tradition to modernity is a typical feature of modern China. Around what kind of country to construct and how to construct the modernity theme of this country, various classes, strata, intellectuals and modern political parties have awakened one after another, showing their different ideas, ideas, designs and efforts to construct China's state. In fact, the formation and evolution of many concepts whose core content is state construction constitute a main line of the occurrence and development of Chinese ideological history since modern times. Among them, the "good government doctrine" advocated by $\mathrm{Hu}$ Shi faction is an important component. Faced with the warlord chaos in the early 1920s and the de facto split and darkness of the state, $\mathrm{Hu}$ Shih's school group put forward the idea of "good government", hoping that "good people" would come to the fore and "good people" would organize the government in order to change the disorder and chaos of "anarchy" in the ideological field and "bad government" in real politics. It reflects the desire of the national bourgeoisie and the petty bourgeoisie for unity and order in China after the capitalist economy developed to a certain extent after the First World War. It conforms to the development trend and trend of modern China's ideological history with the construction of a modern country as the core, and objectively enriches the Chinese people's ideological cognition of democracy and unity. However, this concept of freedom, which was severely divorced from the reality of China at that time, inevitably degenerated into a failed utopia.

\section{V.CONCLUSION}

In a word, there are many common understandings in the ambiguity between the views of liberal based on liberal democracy and Marxist state claims based on class liberation. Also, in the practice of state-building during the May ${ }^{4 \text { th }}$ Movement, liberal intellectuals and Marxists were not enemies, but progressive forces within the democratic front. In order to realize China's sovereignty and independence, national unity and political democracy, the two jointly pointed their criticism at the feudal ideology and autocratic regime, fought side by side to a certain extent, and jointly promoted the growth of the modern Chinese concept of state.

\section{REFERENCES}

[1] Yin Haiguang. Outlook for Chinese culture. Beijing: Commercial Press, 2011.pp.570,573

[2] Hu Shih. My crossroads. The Endeavor, 1922-06-18.

[3] Luo Zhitian. Dream of recreating Civilization: Hu Shi's biography. Chengdu: Sichuan people's publishing house, 1995.pp.248-256.

[4] Hu Shih. Biography of Ding Wenjiang. Beijing: Oriental publishing house, 2009.pp.88-89, 88.

[5] Hu Shih's diary, volume I. Beijing: Zhonghua Book Company, 1985.pp.262,140,165-166,173-175, 234,

[6] $\mathrm{Hu}$ Shih et al. Declaration of Arguing for freedom. The Eastern Miscellany, volume17, issue16, August 25, 1920.

[7] Jerome B. Grieder.Hu Shih and the Chinese Renaissance: Liberalism in the Chinese Revolution (1917-1937).Nanjing: Jiangsu People's Publishing House, 2010.p160.

[8] Hu Shih et al. Our Political Claims. The Endeavor, 1922-05-14.

[9] Hu Shih. This week: demands for Wang Chonghui's cabinet. The Endeavor, 1922-08-12..

[10] W.GT. If we were the premier of state? The Endeavor, 1922-09-17.

[11] Hu Shih. Cai Yuanpei's "non-cooperation". The Endeavor, 1923-01-28. 
[12] Hu Shih's diary, volume II. Beijing: Zhonghua Book Company, 1985.p506.

[13] Dong Qiufang. Discussion on Our Political Claims. The Endeavor, 1922-05-28.

[14] Criticize the "Good Government" Doctrine and its Leader. Pioneer, 1922-06-20.

[15] Hu Weixi et al. Cross Street and Tower: A Study of Liberalis m in Modern China. Shanghai: Shanghai People's Publishing House, 1991.
[16] Zhou Mingzhi, Hu Shih and the Choice of Modern Intellectuals. Nanning: Guangxi Normal University Press, 2005.

[17] Jun Yu. Dr. Wang's life on the stage should be a lesson for "Good People to Work Hard". Guide Weekly, 1922-10-11.

[18] Hu Shih. This week. The Endeavor, 1922-11-26.

[19] Hu Shih. Editor's Note on China's Political Issues by Chen Duxiu. The Endeavor, 1922-09-03. 